\title{
Kadın Çalışanlarda Cam Tavan Algısı Kırıldı mı? Erkek Çalışanlar Halen Cinsiyet Ayrımcılı̆̆ı Yapıyorlar mı?: Adıyaman Bankacılık Sektörü Örneği ${ }^{1}$
}

\author{
DOI: $10.26466 /$ opus.583816
}

*

\section{Gülșen Kırp1k*}

* Dr, Öğr. Üyesi, Adıyaman Üniversitesi, Eczacılık Fakültesi, Adıyaman / Türkiye

E-Posta: gulsenozarslankirpik@gmail.com

ORCID: 0000-0003-4785-9624

Öz

Kadınların iş hayatlarında yükselmelerini önleyen ve ilk olarak 1970'lerde kullanılmaya başlanan "cam tavan sendromu"nun algisal olarak günümüzdeki durumunu ortaya koymak üzere yapılan bu çalışma, Adryaman il ve ilçelerinde faaliyet gösteren bankalardaki çalışanlar üzerinde yapılmıştır. Basit tesadüfi örnekleme yöntemi ile Adıyaman il ve ilçelerinde çalışan 131 banka çalışanı üzerinde uygulanan anket yoluyla veriler toplanmıştır. Araştırmada kullanılan cam tavan algı ölçeğinin güvenilirlik düzeyi $0,815^{\prime}$ dir. Çalı̧̧manın hipotezi Bağımsız $t$-Testi ile analiz edilmiştir. Analiz sonucunda, \%95 güven aralığı içinde $(p=0,006<0,05)$ çalışmanın ana hipotezi olan, $H_{1}$ hipotezi kabul edilmiştir. Çalışmanın sonuçlarına göre, kadın çalışanların cam tavan algısının yok denecek kadar az olduğu, ancak, erkek çalışanlarm önyargısal olarak cinsiyete dayah ayrımcılık yapmaları sebebiyle halen kadın çalışanlara yönelik olumsuz algıya sahip oldukları görülmüştür. Dolayısıyla, kadın çalışanların cam tavan algısının kırıldığ l, ancak erkek çalışanların cinsiyet ayrımı konusunda basmakalıp algilarının devam etmekle birlikte, eskiye nazaran azalma eğiliminde olduğu sonucuna ulaşılmıştır. Çalışmada elde edilen sonuçlar Adıyaman ili ve bankacılık sektöründe çalışanlarla sınırlı olmakla birlikte, söz konusu sonuçlar 2004-2019 yılları arasında ülkemizde yapılan diğer benzer çalışma sonuçları ile farkllıkklar ve benzerlikler açısından karşılaştırılarak, cam tavan alğısının kadın ve erkek çalışanlardaki eğilimine yönelik bilgiler elde edilmiş ve önerilerde bulunulmuştur.

Anahtar Kelimeler: Cam Tavan Sendromu, Cinsiyet Ayrımcılı̆̆ı, Banka Çalı̧̧anları, Adıyaman

\footnotetext{
${ }^{1}$ Bu makale 02-04 Mayıs 2019 tarihinde düzenlenen 18. Uluslararası Işletmecilik kongresinde sözlü bildiri olarak sunulmuş olup, sözkonusu bildiri makale aşamasında yeniden gözden geçirilerek düzeltilmiş ve genişletilmiştir
} 


\title{
Was The Glass Ceiling Perception of The Female Employees Broken up? Are The Male Employees Still Discriminating Gender? The Exampe of Adryaman Banking Sector
}

\begin{abstract}
This study, which was carried out in order to reveal the current status of the glass ceiling syndrome, which was started to be used in the 1970s and prevented women to rise in their business life, was carried out on the employees in the banks operating in the provinces and districts of Adryaman. The data were collected with a questionnaire applied on 131 bank employees working in the provinces and districts of Adryaman by simple random sampling method. The reliability of the glass ceiling perception scale used in the study is 0.815 . The hypothesis of the study was analyzed by Independent $t$-Test. H1 hypothesis was accepted as the main hypothesis of the study in $95 \%$ confidence interval $(p=0.006<0.05)$. According to the results of the study, it is observed that female employees have a low glass ceiling perception, but male employees have a negative perception towards female employees because they have biased discrimination on the basis of gender. Therefore, it has been concluded that the perception of stereotypes of female employees is broken, but the stereotypes of male employees on gender discrimination continue to decrease compared to the past. Although the results obtained in the study were limited to the employees in the province of Adiyaman and the banking sector, the results were compared between the results of the study conducted in our country in the years 2004-2019 in terms of differences and similarities, and information on the tendency of the glass ceiling perception in female and male employees was obtained and recommendations were made.
\end{abstract}

Keywords: Glass Ceiling Syndrome, Gender Discrimination, Bank Employees, Adiyaman 


\section{Giriş}

Sanayi Devrimi'nden sonra iş yaşamına kadınların da dahil olmasıyla beraber iş hayatında kadın varlığı artmış ancak erkek egemen toplum yapıları nedeniyle örgütlerdeki yönetim değişikliği aynı oranda yaşanmamıştır. $\mathrm{Bu}$ durumun ortaya çıkmasında özellikle kültürel, ekonomik, toplumsal ve siyasi gelişmelerin etkisi büyüktür. Kadının toplumdaki yeri ve statüsü üzerine yaşanan tartışmalar halen devam etse de yıllar içerisinde çalışan kadın sayısında artış olmuştur. Ancak, cinsiyete dayalı toplumsal adaletsizlik tümüyle ortadan kalkmamış ve kadınlara karşı toplumsal önyargılar devam etmiştir. "Dünyada erkek egemen bir çalışma sisteminin varlığı her ne kadar sürekli dillendirilen bir durum olarak gözükse de kadınlarda kariyer gelişimi konusu hep çözümsüz kalmıştır. Nihayetinde uluslararası çalışma koşullarındaki ve insan haklarındaki her türlü olumlu gelişmelere karşın günümüzde kadınlar hala çalışma hayatında tam olarak hak ettikleri mevkilere gelememektedir. Bu konuda yapılan araştırmalar kadınlarda kariyer engellerine sebep olan birçok unsurdan bahsedilebilir" (Kara, 2019). Her ne kadar araştırmalar dünya genelinde kadınların iş yaşamına katılımlarında rahatlama ve artış olduğunu gösterse de kadının kendisine daha fazla yer bulmak için halen aşması gereken engeller bulunmaktadır. Bunlardan biri ve belki de en önemlisi ise örgütlerde kadın çalışanların iş hayatında üst düzey pozisyonlara gelebilmelerine engel olarak görülen cam tavan sendromudur.

Kadınların iş yaşamındaki pek çok farklı engeli sembolize eden cam tavan sendromu, çok boyutlu olmasının yanı sıra, disiplinler arası bir anlayışla incelenmesi gereken bir sorundur. Aydın ve Dönmez (2016), cam tavan sendromu sorununu sadece yönetim ve organizasyon kapsamı içerisinde yer alan bir sorun değil, aynı zamanda insan hakları ihlali, istihdam, örgütsel verimlilik ve insani gelişmişlik sorunu olarak da değerlendirmektedir. Bu nedenle, problem her yönüyle tamamen ortaya çıkana kadar konuyla ilgili çalışmaların devam etmesi gerektiği belirtilmiştir.

Korkmaz (2016) tarafından, cam tavanı kırmak için kişinin öncelikle özgüvenini geliştirmesi gerektiği, çünkü kişinin kendine olan güveninin geleceğe olumlu yönde bakmasına sebep olacağı belirtilmiştir. Ayrıca, olumlu yönde algıya sahip kişinin ise hem çevresindeki kişilerin ve hem 
de çalıştığı kurumun bakış açısının olumlu olmasına katkı sağlayacağ1 vurgulanmiştır.

Cam tavan sendromu ile ilgili hem ulusal hem de yabancı yazında çok sayıda araştırmalara rastlanılmıştır. Ancak, son 10 yılda kadın ya da erkek çalışanda cam tavan algisına yönelik olumlu ya da olumsuz yönde bir değişim olup olmadığına ilişkin hem nitel hem de nicel bir araştırmayı kapsayan çalışmaya rastlanılmamıştır. Bu bağlamda çalışma, ilk olarak 1970'lerde kullanılmaya başlanan "cam tavan sendromu" nun algısal olarak günümüz şartlarındaki durumunu ortaya koymak amaciyla yapılmıştır. Kadınların cam tavan algısının halen devam edip etmediği, erkek çalışanların halen cinsiyet ayrımcılığı yapıp yapmadıkları araştırmanın konusunu oluşturmuştur. Bu kapsamda, bu çalışma ile Adıyaman il ve ilçelerinde faaliyet gösteren bankalardaki erkek ve kadın çalışanlar açısından cam tavan sendromunun ne düzeyde algılandığı, erkek çalışan tarafından kadın çalışana yönelik sadece kadın olması sebebiyle cinsiyetinden kaynaklanan ayrımcılığın halen devam edip etmediği, eğer ayrımcılık devam ediyorsa geçmişe nazaran olumsuz algı seviyesinde azalma olup olmadığının araştırılması hedeflenmiştir. Çalışma ile ilgili yazındaki bu boşluğun doldurulacağına inanılmaktadır.

\section{Literatür Özeti}

Çalışmanın bu kımında, cam tavan sendromu ve cam tavan sendromu ile ilgili yapılan bazı benzer çalışmalar hakkında bilgi verilmiştir.

\section{Cam Tavan Sendromu}

İlk olarak 1970'lerde ortaya çıkan ve kadınların çalışma hayatlarında karşılarına çıkan görünmez engelleri tanımlamak amacıyla kullanılan cam tavan sendromu aslında soyut engellerden söz etmektedir. İlk olarak $\mathrm{ABD}$ 'de "kadınların üst kademeye geçmelerini engelleyen görünmez, yapay engeller" olarak tanımlanan kavramı, Cotter "kadınların ve azınlıkların gelişmesine konulmuş yapay bariyerlerdir" şeklinde tanımlamıştır (Wirth, 2001, s.1; Cotter, 2001, s.656; Öğüt, 2006, s.58; Akdemir ve Çalış Duman, 2017, s.517). Lockwood (2004)'a göre ise; Cam tavan kavramı ilk kez, Wall Street'de 
1986 yılında Hymowitz ve Schellhardt'ın yaptıkları "İş yaşamında kadın" konulu söyleşide yer almıştır (Lockwood, 2004; Kulualp, 2015, s.101).

Cam tavan, kadınların üst yönetim mevkilerine ulaşmada gözle görülemeyen ama hissedilen engellerdir. Ayrıca, kadınların çalıştığı herhangi bir kamu kurumunda ya da özel kurumda karşılaşılan, cinsiyete yönelik kişisel, kurumsal ve toplumsal sorunları ifade etmek için kullanılan kavramdır. Gül ve Oktay (2009) tarafından, cam tavanın sadece kadınlarla ilgili bir problem olmadığı, aynı zamanda bireylerin etnik kökenleri ve ırkları ile ilgili olarak iş yaşamında karşılaştıkları ayrımcılık ve engelleri de içerdiği belirtilmiştir. Bu nedenle, Weyer (2006)'e göre cam tavan sendromu, iş yaşamında kadınların ve çeşitli azınlık grupların kariyer basamaklarındaki ilerlemesinin önündeki görünmez örgütsel ve algisal engellerdir (Gül ve Oktay, 2009, s.426).

Cam tavan sendromunda, tavan olgusu yükselmenin önündeki engeli, cam olgusu ise resmi olmayan ve gözle görülmeyen ancak hissedilebilen bir olguyu temsil etmektedir. Genel olarak baktı̆̆ımızda, cinsiyet veya irk farklılıklarından dolayı bireyin örgüt içinde yükselmesinin engellenmesi yani alt kademelerde bilinçli olarak tutulması anlamında kullanıldığı görülmektedir (Sarığlu, 2018, s.31; Erçen, 2008). Esasında sendromun temelinde psikolojik çaresizlik yatmaktadır. Birey, tıpkı sendroma adını veren pire deneyinde olduğu gibi, içerisinde yaşadığ 1 cam tavanları fark eder ve zamanla daha fazlası için çaba sarf etmekten vazgeçer. Bu, sadece sendroma maruz kalan bireyin iş yaşamında ilerlemesini engellemekle kalmaz, aynı zamanda bireyin iş yaşamından ayrılmasına da sebep olur (Sarığlu, 2018, s.32).

Yazında genellikle kadın çalışanlar için kullanılan cam tavan sendromu, kadınların çalışma hayatında karşılaştıkları engellerin tespit edilmesini ve çalışma yaşamlarındaki cam tavan kavramına yönelik farkındalıklarının artmasını sağlamaktadır. Ancak cam tavan sendromu neredeyse tüm toplumlarda kendisine yer edinmiş ve gelişmiş ülkelerde bile farklı yansımaları olmuştur (Yegengil, 2018, s.34). Ayrıca, Erçen (2008) tarafından yapılan çalışmada, kadın emeğinin önündeki "cam tavan" engelinin henüz hiçbir ülkede tam olarak aşılamadığı belirtilmektedir. Örneğin, Baxter ve Wright (2000) tarafından ABD, Avustralya ve İsveç'te karşılaştırmalı olarak yapılan bir çalışmada, cam tavan sendromu çalışma hayatındaki hiyerarşik düzen ve otorite açısından incelenmiştir. $\mathrm{Bu}$ 
çalışma, 21.yüzyılda ve günümüzde insan hakları ve demokrasi, toplumsal cinsiyet eşitliği gibi konularda en gelişmiş ülkelerde bile cam tavan sendromunun devam ettiği görülmüştür. Çalışmaya göre hiyerarşik düzende, düzeyler arasında cinsiyete dayalı ayrımcılık kariyer yükseldikçe artmaktadır.

Yüzyıllardan beri süre gelen cinsiyet ayrımına göre, kadınlar erkeğe bağımlı kılınmış olup, kendi evi ve özel hayatı ile sınırlı kalmak kaydıyla işbölümü yapılmıştır. Erkeğe ise ekonomik açıdan üretken olabileceği işler verilerek kadına göre güçlü kılınmıştır ve toplumsal değer kazanması sağlanmıştır. Bunun sonucunda da, toplumsal olarak kadının yeri evi olarak görülmüştür; kadının görevi ise sadece eş ve anne olarak sınırlandırılmıştır (Karcıoğlu ve Leblebici, 2014, s.2). Daha sonraları sürekli değişim halinde olan dünyada, gerek işgücünün gerek tüketicilerin sosyodemografik özelliklerinde değişimler yaşanmış, kadının statüsü değişmiş ve bunun sonucunda da kadınların yaşamdaki rolleri artarak değişmeye başlamıştır. Bununla birlikte, kadınların işyaşamında aktif rol almasıyla birlikte kariyerlerinde de önemli oranlar da gelişme görülmüştür $(\mathrm{Ku}-$ lualp, 2015, s.100). Her ne kadar kadın çalışanların işgücü içerisindeki payı önemli düzeyde artış gösterse de, Menteş (2018) tarafından Türk Bankacılık sektöründeki cam tavan sorununun incelendiği çalışmada da görüleceği üzere, kadın çalışanların erkeklere oranla eğitim düzeyinin yüksek olmasına rağmen yönetim kurullarında kadın çalışanların yeterli sayıda yer alamadıkları tespiti, halen kadınlara yönelik cinsiyet ayrımcllı̆ının göstergesi niteliğinde sayılabilir. Ayrıca, Yavuz ve Uzun (2019) tarafından yapılan inceleme sonuçları da kadın çalışanların cinsiyet ayrımcılığına maruz kaldıklarını desteklemektedir.

\section{Cam Tavan Sendromu İle İlgili Yapılan Çalışmalar}

Yazında cam tavan sendromu ile ilgili yapılan çalışmalardan bazıları aşağıdaki tabloda özetlenmiştir. Çalışmanın amacı ile uyumlu olması açısından özellikle kadın ve erkek çalışanların cam tavan algısına yönelik elde edilen farklılıklara ilişkin bulguların altı çizilerek gösterilmiştir. 


\section{Gülşen Kırpık}

Tablo 1. Cam Tavan Sendromuna Yönelik Bazı Çalışmalar

\begin{tabular}{lll}
\hline Yazarlar & Yayın Yılı & Araştırma Bulguları \\
\hline & & Bankalarda çalışan kadın / erkek ilk kademe yöneticilerinin, \\
& kadın çalışanların üst düzey yöneticiliğe yükselmelerine \\
& & yönelik tutumlarının cinsiyet açısından anlamlı bir şekilde \\
& farklılaştığı sonucuna ulaşılmıştır. Buna göre, ilk kademe erkek \\
Ergeneli ve Akçamete & yöneticilerin bu konuda kadınlara göre daha olumlu tu- \\
& tumlara sahip oldukları tespit edilmiştir. Çalışmadaki diğer de- \\
& mografik değişkenlerin tutumlar üzerinde anlamlı bir \\
& farklılığına rastlanılmamıştır.
\end{tabular}

Yapılan çalışma sonucunda, mesleki cinsiyet ayırımı, cinsiyet rolleri ve cinsiyet temelli engellerin toplumsal rollerden kaynaklandığı ve söz konusu bu durumun iş yaşamına yansıdığı belir-

Öğ̈̈t, A. tilmiştir. Bu bağlamda, feminize olmuş işlerde kadınların yoğunlaştığı ve dolayısıyla yatay bir mesleki ayırım sergiledikleri belirlenmiştir. Ayrıca, erkek çalışanlara göre daha düşük iş kollarını tercih ederek dikey bir mesleki ayırım sergiledikleri de görülmüştür.

Yöneticilerin cinsiyeti açısından kadın çalışanlar ve kadın Karaca, A. yöneticilere yönelik tutumlar arasında anlamlı farklılık olduğu belirlenmiştir. Bulgular, kadın yöneticilerin kadın çalıșanlar ve kadın yöneticilere yönelik tutumlarının, erkek yöneticilere göre daha olumlu olduğunu ortaya koymuştur.

Çalışmada, Balıkesir ilinde görev yapan 200 çalışana anket uygulanarak elde edilen veriler analiz edilmiştir. Analizler sonu-

Örücü ve diğerleri

Gül ve Oktay

Mizrahı ve Aracı cunda, kadınların üst düzey yönetici pozisyonuna yükselmelerindeki önemli engeller arasında, kadınların ailevi sorumluluklarının fazla olması, liderlik ve yöneticilik özelliklerinin sınırlı olması ve "kraliçe arı (kadınların birbirini çekememesi) sendromunun" yer aldığı belirtilmiştir.

Bu çalışmada, eğitim ve gelişmişlik düzeyi, cam tavan algısını aşmak için önemli faktörler olarak görülmüştür. Ancak, cam tavan algısının gelişmiş toplumlarda bile tartışılması, ayrımcılı̆̆ın halen var olduğu, sosyal yaşamda çok sayıda rol üstlenen kadınların, bu algıyı yıkmak yerine çeşitli nedenlerle kabullenmeyi tercih ettikleri ve ayrıca kadınların teknolojik yönü ağır basan yeni sektörlerde engel olarak sadece rekabeti gördükleri ortaya konulmuştur. Bu araştırmaya göre, cam tavan algısının, geleneksel yöntemlerden uzak iş ortamlarında yer bulmadığı sonucuna ulaşılmıştır.

Kadınların üst düzey yöneticilik pozisyonlarına ulaşmalarına engel olan ve cam tavan algısına sebep olan bireysel, örgütsel ve toplumsal unsurlar teorik bir kapsamda incelenmiştir. İzmir ilinde faaliyet gösteren KOBI'lerden üzerinde yapılan araştırma sonucunda, kadın çalıșanlardaki cam tavan algısının erkek çalıșanlardan daha yüksek ve anlamlı olduğu belirlenmiştir. Çalışmada İslami okullar ve İslami kolejlerde, İslami Okullar için iki Öğrenme Yardımı Programı faaliyetinden (LAPIS) elde edilen verilere dayanarak kadınların liderlik ve karar alma konusundaki temsilleri araştırmak için yürütülen çalışma sonucunda Endonezya' da kadınların yöneticilik becerilerini geliştirmelerini sağlayacak eğitimlere erkeklerden daha az katılım 


\begin{tabular}{|c|c|c|}
\hline & & $\begin{array}{l}\text { gösterdiği, dolayısıyla da ülkede cam tavan sendromunun } \\
\text { halen etkisini sürdürdüğü tespit edilmiştir. }\end{array}$ \\
\hline Bingöl ve diğerleri & 2011 & $\begin{array}{l}\text { Yapılan çalışma sonucunda, cam tavan algısı açısından tutum } \\
\text { düzeyleri arasında sadece cinsiyet değişkenine göre anlamlı } \\
\text { farklılık bulunmuştur. Buna göre, kadın yöneticilerin kadın } \\
\text { çalıșanlara yönelik, erkek yöneticilere göre daha olumsuz tu- } \\
\text { tum sergiledikleri sonucuna ulaşılmıştır. Araştırma bulguları, } \\
\text { erkek çalışanların, kadın çalışanların üst düzey pozisyonlara } \\
\text { çıkmalarına yönelik bakış açılarının kadın çalışanlara göre daha } \\
\text { ılımlı olduklarını ortaya koymuştur. Ayrıca, bu durum kadın- } \\
\text { ların cam tavan sendromunu yaşadıklarının bir göstergesi } \\
\text { olduğu gibi aynı zamanda kadınlardan kaynaklanan bir } \\
\text { öğrenilmiş çaresizlik kavramı ile de karşımıza çıkmaktadır. }\end{array}$ \\
\hline Taşkın, E. & 2012 & $\begin{array}{l}\text { Bursa il merkezinde } 42 \text { tekstil işletmesinde çalışan kadın yöneti- } \\
\text { ciler üzerinde yapılan çalışma sonucunda, kadın yöneticilerin } \\
\text { cam tavan algılarının çocuk sayıları açısından anlamlı farklılık } \\
\text { gösterdiği ancak diğer demografik özelliklere göre farklılık } \\
\text { göstermediği belirlenmiştir. }\end{array}$ \\
\hline Aksu ve diğerleri & 2013 & $\begin{array}{l}\text { Cam tavanı ortaya çıkaran unsurların ve cam tavanı aşma } \\
\text { stratejilerinin belirlenmesi amacıyla yürütülen çalışma, İzmir İli } \\
\text { Buca İlçesi İlköğretim okullarında görev yapmakta olan } 4 \text { kadın } \\
\text { ve } 6 \text { erkek müdür üzerinde yapılmıştır. Çalışma sonucunda } \\
\text { kadınların cam tavanı aşma stratejilerinin yüksek performans } \\
\text { gösterme, eğitim durumları, danışmanlardan ve sosyal } \\
\text { ilişkilerden faydalanma olduğu tespit edilmiştir. }\end{array}$ \\
\hline
\end{tabular}

Kadın yöneticilerdeki kariyer engelleri ve cam tavan sendromu arasındaki ilişkinin incelenmesi amacıyla, Erzurum'daki kamu ve özel banka şubelerinde çalışan 40 bayan ve 40 erkek olmak üzere 80 kişi üzerinde yapılan araştırma sonucunda, bankacılık sektöründe kadınların kariyerlerinde ilerleyememelerinde göre cam tavan sendromunun etkili olduğu sonucuna ulaşılmıştır. Yöneticilerin cinsiyetine göre, kadın çalışanlara ve kadın yöneticilere ait tutumların farklılık gösterdiği belirlenmiştir. Buna göre, günümüzde kadın yöneticiler iyi bir es, iyi bir anne ve başarılı bir yönetici olabileceklerine inanmaktadırlar. Ancak, erkek yöneticiler bu konuda kararsız kalmaktadırlar. Erkek yöneticilerin kararsız kalması, kadınlara yönelik geleneksel düsüncelerin tamamen değissmediğini göstermektedir.

Kadın öğretmenlerin cam tavan sendromu algısı üzerinde öğrenilmiş çaresizliğin ve seçilen sosyo-demografik değişkenÇizel, R. ve Çizel, B. $\quad 2014$ lerin etkisini inceleyen araştırmada, Antalya ilindeki özel okullarda çalışan kadın öğretmenlerin işyerinde yaşadıkları cam tavan sendromunun incelenmesi ile sosyo-demografik değişkenlerle birlikte öğrenilmiş çaresizlik gibi psikolojik değişkenlerin de araştırılması gerektiği belirlenmiştir.

İstanbul'da Sanayi işletmelerinde çalışan 350 kişi ile yapılan çalışmadır. Sonuçlar kadın ve erkeklere göre cam tavan sendromu düzeyinin \% 99 düzeyinde istatistiksel olarak anlamlı bir şekilde ayrıldığını ortaya koymaktadır. Toplam cam tavan değerleri için grup ortalamalarına bakıldığında kadınların 83,15 puan almalarına karşın erkeklerin 99,98 aldıkları görülmektedir. Bu durum, erkeklerin kadınlara nazaran daha fazla cam tavan uygulamasını mazur gördüklerini ifade etmektedir. Buna 


\section{Gülşen Kırpık}

göre, halen günümüzde kadınların evlerinde oturmalarının daha doğru olduğunu düșünebilen erkeklerin olduğu görülmüstür.

Çok sayıda kadın çalışan barındıran sağlık sektöründe cam tavan kavramını incelemek amacıyla yürütülen çalışma sonucunda kadınların bireysel faktörlerle ilgili olan iletişim, ön yargılar, kişisel tercih algıları gibi konularda cam tavan engelleri ile karşılaşsa dahi aşabilme potansiyeline sahip olduğu ancak toplumsal veya örgütsel faktörlerle ilgili olan stereotipler, mesleki ayrımclık, mentor eksikliği, örgüt kültürleri ve politikaları gibi konularda ciddi bir cam tavan engeline takıldıkları tespit edilmiştir.

Bu çalışma, derleme niteliğinde olup, çalışmanın amacı, cam uçurum kavramının tanıtılması, cam uçurum hakkında yapılan çalışmaların özetlenmesidir. Çalışma sonucunda, kadınların kriz dönemlerinde birer kriz yöneticisi olarak algılandığı ve stresle başa çıkma konusunda daha iyi olduklarının düşünüldüğü için bunun kadınları "hileli cam uçurum" pozisyonlarına sürüklediği vurgulanmaktadır.

Erzurum, Erzincan, Bayburt illerinden oluşan TRA-1 Düzey bölgesinde bulunan Erzurum Atatürk Üniversitesinde 150, Erzincan Üniversitesinde 107, Bayburt Üniversitesinde 88 akademisyen, memur ya da şirket elemanı olarak serbest çalşan ve


çoğunluğunu kadınların oluşturduğu 345 kişi üzerinde uygulanan anket ile Çelişik Duygulu Cinsiyetçilik ile beraber Cam Tavan Sendromu incelenmiştir. Çalışma sonucunda Çelişik Duygulu Cinsiyetçilik davranışları ile Cam Tavan Sendromu arasında anlamlı bir ilişki olduğu tespit edilmiştir.

Üst medya yönetimindeki kadınların başarılı deneyimlerini ve cam tavan faktörlerine karşı tutumlarını, hangi faktörleri önemli Love, J. F. olarak algıladıkları ve başarılarında yardımcı olabilecek diğer faktörleri belirlemek amacıyla yapılan çalışmada toplam 114 medya yöneticisine anket uygulanmış ve neredeyse yarısının $(\% 45,54)$ cam tavanı yönetim kariyerlerinde kısıtlama konusunda tecrübe etmedikleri tespit edilmiştir.

Çalışma cam tavan sendromu metaforunun kullanımının üzerinden geçen 30 yıl boyunca farklı Asya ülkelerinde yürütülen farklı cam tavan çalışmalarını analiz etmek amacıyla

Lathabavan ve 2017 Balasubramanian yapılmıştır. Çalışmada Asya ülkeleri ile ilgili uluslararası kurumlar tarafından çıkarılan raporlar incelenmiştir. Çalı̧̧a sonucunda Asya ülkelerinde toplumsal cinsiyet eşitsizliğine bağlı olarak cam tavan sendromunun halen görüldüğü, ancak özellikle uluslararası girişimler sayesinde bunun aşılmaya başlandığı tespit edilmiş̧ir.

Çalışmada, kadın çalışanlar, yöneticilik yaparken hem iyi bir eș hem iyi bir anne hem de iyi bir yönetici olacağına kesinlikle katılmakta ve bu konuda iddialıdırlar. Bunun aksine erkeklerin bu görüșe katılmadığı görülmüștür.
“Kadınların ailevi sorumluluklarının fazla olması üst düzey görevlerde yer almasına engeldir" görüșünü erkek katılımcılar desteklemisțir. Kadınların ailevi sorumluluklarının fazla olmasının üst düzey görevlerde yer almasina engel olduğu görüşündedirler. 


\begin{tabular}{|c|c|c|}
\hline Bilkay, T. A. & 2017 & $\begin{array}{l}\text { Çalıșmaya katılan kadın çalıșanlarda cam tavan algısı olma- } \\
\text { dığı bilimsel olarak ortaya çıkmıștır. Ancak cam tavan algısı } \\
\text { olduğunu gösteren ifadelere verilen cevapların yüksek olması } \\
\text { (Benim için birinci öncelik çocuğumla ilgilenmektir ve üst } \\
\text { düzey yöneticilik için erkeklere daha çok fırsat veriliyor gibi) } \\
\text { yine de bir algının oluştuğunu göstermektedir. Bu ifadelerden } \\
\text { birincisi çoklu rol üstlenmeye, ikincisi ise mesleki konularda } \\
\text { cinsiyet ayrımcılığına dikkat çekmektedir. }\end{array}$ \\
\hline Demir ve Kartal & 2018 & $\begin{array}{l}\text { Sağlık çalışanları üzerinde yapılan bu çalışmada, sağlık çalışan- } \\
\text { larının orta düzeyde bir cam tavan algısına sahip oldukları, cam } \\
\text { tavan algısının cinsiyet açısından anlamlı farklılık gösterdiği, } \\
\text { ancak diğer değişkenler açısından anlamlı farklılık gösterme- } \\
\text { diği belirlenmiştir. Cinsiyet açısından anlamlı farklılık düzeyleri } \\
\text { incelendiğinde kadın çalıșanlardaki cam tavan algısının erkek } \\
\text { çalıșanlara göre daha yüksek olduğu sonucuna ulaşılmıştır. }\end{array}$ \\
\hline Ertaş ve diğerleri & 2018 & $\begin{array}{l}\text { Bu çalışmada, araştırmaya katılan kadınlar kendilerine } \\
\text { yönelik kariyer engelleri olduğunu düşünmemektedirler. } \\
\text { Kadın çalışanlar, üst düzey yöneticilik pozisyonlarına } \\
\text { yükselmelerinde, ailevi sorumluluklarını bir engel olarak } \\
\text { görmemekte ve üst düzey yöneticilikte başarılı olabileceklerine } \\
\text { inanmaktadırlar. Diğer taraftan, kadın çalışanlar üst düzey } \\
\text { yöneticiliklerin kadınlardan çok erkeklere verildiğini, terfi ko- } \\
\text { nusunda da kendilerine daha fazla imkân verilmesi gerektiğini } \\
\text { düşünmektedirler. Ayrıca kadının, toplumsal rolü nedeniyle } \\
\text { çalışanlar, kadınlara çok fazla ailevi sorumluluk yüklendiğini } \\
\text { belirtmişlerdir. }\end{array}$ \\
\hline Yavuz ve Uzun & 2019 & $\begin{array}{l}\text { Bu çalışmanın bulgularına göre, cam tavan sendromunu ne- } \\
\text { redeyse her sektördeki ve her kademedeki kadın çalışanlar al- } \\
\text { gılamakta ve yaşamaktadır. İncelenen çalışmaların büyük } \\
\text { çoğunluğu kadınların cam tavan engelleri ile karşılaştığını ve } \\
\text { cinsiyet ayrımcılığına maruz kaldıklarını destekler niteliktedir. } \\
\text { Tüm bunlara bakıldığında toplumsal cinsiyet algısının sebep } \\
\text { olduğu önyargılar kadınların iş hayatında kariyerlerindeki } \\
\text { yükselmelerinin önünde engel oluşturmaktadır. Bu önyargılara } \\
\text { göre kadınlara üst düzey yöneticilik pozisyonları uygun bulun- } \\
\text { mamaktadır. }\end{array}$ \\
\hline
\end{tabular}

Yukarıdaki çalışmalar birlikte değerlendirildiğinde, ülkemizde toplumsal cinsiyet eşitsizliği nedeniyle cam tavan sendromunun halen devam ettiği, özellikle her sektör ve her yönetim kademesinde sözkonusu sendromun yaşandığı anlaşılmaktadır. Bu çalışmanın Türkiye'nin güneyindeki Adıyaman ilinde yapılması sebebiyle, bu ilin bankacılık sektöründeki kadın ya da erkek çalışanda cam tavan algısına yönelik olumlu ya da olumsuz yönde bir değişim olup olmadığına ilişkin elde edilecek bulguların ilgili yazındaki bilgi birikimine destek olacağı düşünülmüştür. 


\section{Araştırma}

Çalışmanın bu bölümünde araştırmanın amacı, hipotezleri, ana kütle ve örneklem, analiz yöntemi, cam tavan sendromu ölçeğinin güvenilirliği gibi konulara yer verilmiştir.

\section{Araştırmanın Amacı ve Stnırları}

Adıyaman il ve ilçelerinde faaliyet gösteren bankalarda çalışan kadın ve erkek çalışanların, kadın çalışanların iş yaşamlarında yöneticilik pozisyonlarında görev almalarına ilişkin karşılaştıkları cam tavan algısından kaynaklanan engellerin günümüz şartlarında halen devam edip etmediğinin ve söz konusu cam tavan algısının geçmiş ile karşılaştırılarak bugün itibariyle kadın ve erkek çalışanlar açısından cam tavan algı düzeyinin ne durumda olduğunun belirlenmesi bu çalışmanın amacını oluşturmuştur. Bu bağlamda, araştırmaya katılan hem kadın hem de erkek çalışanların cam tavan sendromuna yönelik algı düzeyleri ölçülecek ve kadın çalışan ile erkek çalışan arasında algısal farklılık olup olmadığ incelenecektir. Ayrıca, bu çalışma ile elde edilecek bulgular ışığında, literatürde yer alan bazı benzer çalışma sonuçları ile karşılaştırmalar yapılacak, sonuçlar tartışılacak ve konu ile ilgili diğer araştırmacılara da yol gösterilecektir.

Bu çalışma, Türkiye'nin Güneydoğu bölgesinde faaliyet gösteren banka çalışanlarının küçük bir örneğini ele almıştır. Bulgular, sosyo-demografik, teknolojik, kültürel ve ekonomik özelliklerin farklılaştığı diğer bölge ve illerdeki banka çalışanları için genelleştirilemeyebilir. Çünkü, kadın çalışanlara yönelik cam tavan algısını etkileyen sosyo-demografik, kültürel, teknolojik ve ekonomik faktörlerin bölgeler arası farklılıklar göstermesi olağandır.

Ayrıca, araştırmaya katılan çalışanların anket sorularını doğru şekilde ve aynı yönde anlayıp anlamadıkları konusunda çalışma sınırlılığ mevcuttur. Ancak, cevaplayıcıların soruları şekilde ve aynı yönde anladıkları varsayılarak, verilen cevapların gerçek durumu yansıttığı kabul edilmiştir. 


\section{Araştırmanın Hipotezleri}

Araştırmanın amacına bağlı olarak geliştirilen hipotezler aşağıda verilmiştir.

- Ho: Cam tavan algısı, çalışanın cinsiyetine göre farklılık göstermemektedir.

- H1: Cam tavan algısı, çalışanın cinsiyetine göre farklılık göstermektedir.

\section{Anakütle ve Örneklem}

Adıyaman il ve ilçelerinde faaliyet gösteren kamu ve özel bankalarda çalışanlar bu araştırmanın ana kütlesini oluşturmaktadır. Türkiye Bankalar Birliği Başkanlığı sitesinden alınan verilere göre Adıyaman'da faaliyet gösteren bankalardaki çalışan sayısı 439'dur (https://www.tbb.org.tr). Çalışma kapsamında Adıyaman il ve ilçelerinde bulunan bankalara toplam 250 adet anket dağıtılmış olup, geri dönen 164 anketin 131'inin kullanılabilir olduğu görülmüştür. Buna göre 131 anket ile elde edilen veri seti ile çalışmanın amacına ulaşılmaya çalışılmıştır. Örneklem seçiminde basit tesadüfi yöntem kullanılmıştır. Anakütlenin \%29,84'üne ulaşılmıştır. Örneklemin yeterliliği açısından, Yazıcıoğlu ve Erdoğan (2004) tarafından verilen bilgiler ile özellikle zaman ve maliyet kısıtları da dikkate alınarak örneklemin yeterli olduğuna karar verilmiştir.

\section{Verilerin Toplanması ve Analiz Yöntemi}

Araştırma, Adıyaman il ve ilçelerinde faaliyet gösteren bankalardaki çalışanlar üzerinde yapılmıştır. Kadın ve erkek çalışan açısından cam tavan algısına ilişkin olumlu ya da olumsuz yöndeki farklılıkların istatistiksel açıdan belirlenmesi amacıyla, yüz-yüze anket yöntemi ile verilere birincil kaynaktan ulaşılmıştır. Hazırlanan anket formları için öncelikle pilot bir uygulama yapılmıştır. Pilot uygulama sonucunda anketlerin güvenilirlik yüksek bulunduğundan çalışmanın devamına karar verilmiştir.

Araştırmada kullanılan anket, çalışanın demografik özelliklerine (6 soru) ilişkin sorular ile cam tavan algısının ölçümüne ilişkin 21 ifadeli 
"cam tavan algısı ölçeği" değişkenlerinden oluşmaktadır. "Cam Tavan Algısı" ölçeğinin oluşturulmasında, Ertaş, Çiftçi Kıraç ve Kıraç (2018), Girginer ve Ertuğ (2017), Bingöl, Aydoğan, Şenel ve Erden (2011) ve Karaca (2007) tarafından yapılan çalışmalardaki anket çalışmalarından yararlanılmiştır.

Cam tavan sendromu algısını ölçmek için Likert tarzı ölçekler kullanılmıştır. Bu bağlamda 1 "Kesinlikle Katılmıyorum" ile 5 "Kesinlikle Katıl1yorum" arasında değişen 5'li Likert tipi ölçek ile hazırlanmıştır. Anket formu, 2018 Mart-Aralık aralığındaki dönemde uygulanmıştır. Veri setinin çözümlenmesi için "SPSS 16.0" paket programından yararlanarak araştırma hipotezlerinin analizi yapılmıştır.

\section{Ölçüm Aracının Güvenilirliği}

$\mathrm{Bu}$ araştırmada kullanılan, cam tavan algı ölçeğinin Cronbach's Alpha katsayısı hesaplanarak güvenilirlik değerine ulaşılmıştır.

Tablo 2. Güvenilirlik Analizi Sonuçları

\begin{tabular}{lll}
\hline Uygulama & Test Türü & Sonuç \\
\hline Cam Tavan Sendromu Alg1 Ölçeği & Cronbach's Alpha (21) & 0,815 \\
\hline
\end{tabular}

Tablo 2'de görüleceği üzere, 21 değişkenden oluşan "Cam Tavan" alg1 ölçeğinin Cronbach's Alpha değerinin 0,815 olduğu belirlenmiştir. Kalayc1 (2016) tarafından verilen bilgilere göre, ölçeğin yüksek derecede güvenilir olduğu söylenebilir.

\section{Araştırma Bulguları}

Çalışmanın bu kısmında, katılımcıların sosyo-demografik özellikleri ile cam tavan sendromu algı düzeylerine yönelik tanımlayıcı istatistiksel bulgulara yer verilmiştir.

\section{Tanımlayıcı Bulgular}

Araştırmaya katılan çalışanların cinsiyet, medeni durum, eğitim düzeyi, kıdem düzeyi, yaş aralığı ve görev durumu gibi sosyo-demografik 
özelliklerine ilişkin dağılımlar aşağıdaki tabloda gösterilmiştir.

Araştırmaya katılan çalışanların \%36,6'sının kadın, \%63,4'ünün ise erkek çalışandan oluştuğu; \%53,4'ünün evli, \%46,6'sının bekar olduğu; $\% 7,6^{\prime}$ sının lise, $\% 22,9^{\prime}$ unun önlisans, $\% 57,3^{\prime}$ ünün lisans ve $\% 12,2^{\prime}$ sinin ise yüksek lisans ve üstü mezunu olduğu; \%7,6'sının 1 yıldan az, \%50,4'ünün 1-5 yıl, \%28,2'sinin 6-10 yıl, \%8,4'ünün 11-15 yıl ve \%5,4'ünün ise 16 yıl ve üzeri kıdem düzeyine sahip olduğu; \%67,9'unun 24-38 yaş, \%28,3'ünün $39-58$ yaş, \%2,3'ünün 23 ve aşağısı yaş, \%1,5'inin ise 59 ve üstü yaş aralığında olduğu; \%71'inin müşteri temsilcisi, \%13,0'ünün şef, \%7,7'sinin müdür ve müdür yardımcısı ve $\% 8,3$ 'ünün ise yardımcı hizmetler olarak görev yaptıkları görülmüştür.

Tablo 3. Tanımlayıcı Bulgular

\begin{tabular}{|c|c|c|c|c|c|c|c|}
\hline \multicolumn{2}{|c|}{ Demografik Özellikler } & \multirow{3}{*}{$\begin{array}{l}\mathbf{n} \\
83 \\
48\end{array}$} & \multirow{3}{*}{$\begin{array}{l}\% \\
63,4 \\
36,6 \\
\end{array}$} & \multicolumn{2}{|c|}{ Demografik Özellikler } & \multirow{3}{*}{$\begin{array}{l}\mathbf{n} \\
70 \\
61\end{array}$} & \multirow{3}{*}{$\begin{array}{l}\% \\
53,4 \\
46,6\end{array}$} \\
\hline \multirow{2}{*}{ Cinsiyet } & Erkek & & & \multirow{2}{*}{$\begin{array}{l}\text { Medeni } \\
\text { Durum }\end{array}$} & Evli & & \\
\hline & Kadın & & & & Bekar & & \\
\hline \multirow{4}{*}{$\begin{array}{l}\text { Eğitim } \\
\text { Düzeyi }\end{array}$} & Lise & 10 & 7,6 & \multirow{4}{*}{$\begin{array}{l}\text { Yaş } \\
\text { Aralığı }\end{array}$} & $\begin{array}{l}23 \text { yaş } \\
\text { ve aşağı1 }\end{array}$ & 3 & 2,3 \\
\hline & Önlisans & 30 & 22,9 & & $24-38$ yaş & 89 & 67,9 \\
\hline & $\begin{array}{l}\text { Lisans } \\
\text { Yijkssk }\end{array}$ & 75 & 57,3 & & $39-58$ yaş & 37 & 28,3 \\
\hline & $\begin{array}{l}\text { Yuksek } \\
\text { Lisans } \\
\text { ve üstü }\end{array}$ & 16 & 12,2 & & $\begin{array}{l}59 \text { yaş } \\
\text { ve üstü }\end{array}$ & 2 & 1,5 \\
\hline \multirow{5}{*}{$\begin{array}{l}\text { Kıdem } \\
\text { Düzeyi }\end{array}$} & 1 yıldan az & 10 & 7,6 & \multirow{5}{*}{$\begin{array}{l}\text { Görev } \\
\text { Durumu }\end{array}$} & $\begin{array}{l}\text { Müdür ve } \\
\text { Müd. Yrd. }\end{array}$ & 10 & 7,7 \\
\hline & $1-5$ yıl & 66 & 50,4 & & Şef & 17 & 13,0 \\
\hline & 6-10 yıl & 37 & 28,2 & & $\begin{array}{l}\text { Müşteri } \\
\text { temsilcisi }\end{array}$ & 93 & 71,0 \\
\hline & $\begin{array}{l}11-15 \text { yıl } \\
16 \text { yıl } \\
\text { ve üzeri }\end{array}$ & $\begin{array}{l}11 \\
7\end{array}$ & $\begin{array}{l}8,4 \\
5,4\end{array}$ & & $\begin{array}{l}\text { Yardımcı Hiz- } \\
\text { metler }\end{array}$ & 11 & 8,3 \\
\hline & Toplam & 131 & 100,0 & & Toplam & 131 & 100,0 \\
\hline
\end{tabular}

Tanımlayıcı değişkenlere ilişkin istatistik sonuçları değerlendirildiğinde, bu çalışmaya katılan çalışanların, çoğunluğunun erkek, genç ve müşteri temsilcisi çalışanlardan oluştuğu, çalışanların çoğunluğunun lisans ve üstü eğitim seviyesine sahip olduğu, kıdem düzeylerinin çoğunlukla 5 yıl ve aşağısında olduğu gözlenmiştir. 


\section{Araştırmaya Katılan Çalışanların Cam Tavan Algı Düzeylerine Yönelik Tanımlayıcı Bulgular}

Bu bölümde, cam tavan algısına ilişkin verilen cevaplar "1 -Katılmıyorum”, “2-Fikrim yok” ve "3-Katıllyorum” şeklinde değişen 3'lü Likert tipi ölçeğe dönüştürülerek, tanımlayıcı istatistiki bilgilere ulaşılmıştır. Çalışmanın bu kısmında, araştırmaya katılan çalışanların cam tavan algı düzeyine ilişkin elde edilen veriler, tanımlayıcı istatistiki bilgilere ulaşılmıştır. Bu bağlamda, araştırmaya katılan çalışanların cam tavan algı düzeyine yönelik tanımlayıcı istatistikler Tablo 4'de gösterilmiştir.

Tablo 4. Katılımcıların Cam Tavan Algılarına İlişkin Bulgular

\begin{tabular}{|c|c|c|c|c|c|c|c|c|}
\hline \multirow{2}{*}{$\begin{array}{l}\text { Cam Tavan } \\
\text { Algısı İfadeleri } \\
\text { Kadın çalışanlara yönelik; }\end{array}$} & \multicolumn{2}{|c|}{ Katılmiyorum } & \multicolumn{2}{|c|}{ Fikrim yok } & \multicolumn{2}{|c|}{ Katıliyorum } & \multirow[b]{2}{*}{ Ortalama } & \multirow{2}{*}{$\begin{array}{l}\text { Standard } \\
\text { Sapma }\end{array}$} \\
\hline & F & $\%$ & $\mathbf{F}$ & $\%$ & $\mathbf{F}$ & $\%$ & & \\
\hline CTA1 & 73 & 55,7 & 8 & 6,1 & 50 & 38,2 & 1,8244 & ,08358 \\
\hline CTA2 & 99 & 75,6 & 10 & 7,6 & 22 & 16,8 & 1,4122 & 06669 \\
\hline CTA3 & 41 & 31,3 & 19 & 14,5 & 71 & 54,2 & 2,2290 & ,07857 \\
\hline CTA4 & 94 & 71,8 & 14 & 10,7 & 23 & 17,5 & 1,4580 &, 06790 \\
\hline CTA5 & 84 & 64,2 & 21 & 16,0 & 26 & 19,8 & 1,5573 & ,07037 \\
\hline CTA6 & 76 & 58,0 & 21 & 16,0 & 34 & 26,0 & 1,6794 & ,07529 \\
\hline CTA7 & 84 & 64,2 & 21 & 16,0 & 26 & 19,8 & 1,5573 & ,07037 \\
\hline CTA8 & 75 & 57,3 & 17 & 13,0 & 39 & 29,7 & 1,7252 & ,07819 \\
\hline CTA9 & 84 & 64,2 & 18 & 13,7 & 29 & 22,1 & 1,5802 & 07266 \\
\hline CTA10 & 73 & 55,7 & 16 & 12,2 & 42 & 32,1 & 1,7634 & ,07951 \\
\hline CTA11 & 58 & 44,3 & 23 & 17,5 & 50 & 38,2 & 1,9389 & ,07945 \\
\hline CTA12 & 79 & 60,3 & 19 & 14,5 & 33 & 25,2 & 1,6489 & ,07502 \\
\hline CTA13 & 65 & 49,6 & 17 & 13,0 & 49 & 37,4 & 1,8779 & 08111 \\
\hline CTA14 & 77 & 58,8 & 19 & 14,5 & 35 & 26,7 & 1,6794 & ,07607 \\
\hline CTA15 & 81 & 61,8 & 16 & 12,2 & 34 & 26,0 & 1,6412 & ,07591 \\
\hline CTA16 & 43 & 32,8 & 26 & 19,9 & 62 & 47,3 & 2,1450 & ,07748 \\
\hline CTA17 & 92 & 70,2 & 14 & 10,7 & 25 & 19,1 & 1,4885 &, 06970 \\
\hline CTA18 & 33 & 25,2 & 20 & 15,3 & 78 & 59,5 & 2,3435 & ,07490 \\
\hline CTA19 & 42 & 32,1 & 12 & 9,1 & 77 & 58,8 & 2,2672 & ,08024 \\
\hline CTA20 & 51 & 38,9 & 23 & 17,6 & 57 & 43,5 & 2,0458 & ,07953 \\
\hline CTA21 & 77 & 58,8 & 21 & 16,0 & 33 & 25,2 & 1,6641 & ,07478 \\
\hline
\end{tabular}

Kısaltmalar: CTA1: Bankacılık sektöründe çalışan kadınlar iş hayatının güçlüklerine erkekler kadar direnç gösteremezler; CTA2: Bankacılık sektöründe çalışan kadınlar hızlı ve mantıksal kararlar alamazlar; CTA3: Bankacılık sektöründe çalışan kadınlar erkeklere göre, uzun mesailere, şehirlerarası ya da ülkeler arası seyahatlere daha soğuk bakarlar; CTA4: Bankacılık sektöründe 
çalışan kadınlar kariyerlerine erkekler kadar bağlı değildir; CTA5: Kadınlar erkeklere göre daha duygusal olduğu için üst düzey yöneticilikte başarılı olamazlar; CTA6: Kadının yeri eşinin yanıdır; CTA7: Bankacılık sektöründe üst düzey yönetici olarak görev yapmak kadınların cinsel kişiliğini olumsuz etkiler; CTA8: Bankacılık sektöründe çalışan kadınlar, görev dağılımı konusunda cinsel ayrımcılığa maruz kalırlar.; CTA9: Bankacılık sektöründe çalışan kadınlar, terfi etme konusunda cinsel ayrımcılığa maruz kalırlar; CTA10: Bankacılık sektöründe çalışan kadınlara, üst düzey yöneticilik için erkeklerden daha az fırsat veriliyor; CTA11: Kadınlar erkeklerin baskın olduğu iletişim ağlarına girmekte zorlanırlar; CTA12: Çalıştığım bankadaki kadın çalışanlar üst düzey yönetici kademelerine ulaşmada etkili olan kritik görevlerde yeterince yer alamazlar; CTA13: Bankacılık sektöründe rol model olabilecek yeterli sayıda kadın yönetici yok; CTA14: Bankacılık sektöründe kadınların mesleklerinde ilerlemeleri için erkeklere göre daha çok çalışmaları gerekiyor; CTA15: İş yerimde kadın ve erkeklere yönelik eşit performans değerlemesi yapılmamaktadır; CTA16: Bankacılık sektöründeki hayat, kadınların iyi bir anne olmasını engeller; CTA17: Bankacılık sektöründeki kadınların yönetmekten çok yönetilmeleri gerekir; CTA18: Kadın için birinci öncelik çocuğuyla ilgilenmektir; CTA19: Kadınlar ailede erkeklerden daha fazla sorumluluk üstlenir; CTA20: Kadınlar başarılı bir yönetici olmak için yeterli zamana sahip değildir; CTA21: Bankacılık sektöründe çalışan kadınlar, görev, birimi, yükselme ve ödüllendirme gibi konularda cinsel ayrımcılığa maruz kalırlar.

SPSS 16.0 paket programı ile 5'li Likert ölçeğinden 3’lü Likert ölçeğinee dönüştürülen ölçeğin nötr puanı 2,00 olarak belirlenmiştir. Microsoft Excell programında yapılan istatistiksel çalışma ile, araştırmaya katılan 131 çalışanın genel alg1 düzeyi ortalamasının $(2,47>2,00)$ "olumsuz" yönde olduğu görülmektedir. Buna göre, araştırmaya katılan çalışanların cam tavan alg1 düzeyinin 2,00'den yüksek olması cam tavan algısının ve dolayısıyla cinsiyete yönelik ayrımcılığın halen devam ettiğini göstermektedir.

\section{Bağımsız İki Örnek T-Testi}

Araştırma hipotezi, çalışmanın bu kısmında Bağımsız iki örnek t-testi ile analiz edilmiştir. Çalışanın kadın ya da erkek olmasına göre cam tavan alg1 farklılıklarının incelenmesi için, öncelikle cam tavan algısını oluşturan tüm değişkenlerin ortalamasına ve standart sapmasına bakılmıştır. Cam tavan algısı hem genel hem de değişkenler açısından değerlendirilmiştir. 
Tablo 5. Cam Tavan Algısının Değişkenleri Açısından Bağımsız t-Testi Sonuçları

\begin{tabular}{|c|c|c|c|c|c|c|}
\hline & Cinsiyet & $\mathrm{N}$ & Ortalama & Std. Sapma & $\mathrm{t}$ & $\mathrm{p}$ \\
\hline \multirow[t]{2}{*}{ CTA1 } & Erkek & 83 & 3,0964 & 1,32163 & & \\
\hline & Kadın & 48 & 1,8958 & ,99444 & $5,883^{*}$ & ,000 \\
\hline \multirow[t]{2}{*}{ CTA2 } & Erkek & 83 & 2,4337 & 1,04989 & & \\
\hline & Kadın & 48 & 1,6042 & ,76463 & $5,199^{*}$ & ,000 \\
\hline \multirow[t]{2}{*}{ СТАЗ } & Erkek & 83 & 3,5060 & 1,15160 & & \\
\hline & Kadın & 48 & 2,7083 & 1,14777 & $3,825^{*}$ & ,000 \\
\hline \multirow[t]{2}{*}{ CTA4 } & Erkek & 83 & 2,5301 & 1,11899 & & \\
\hline & Kadın & 48 & 1,6458 & 72902 & $5,468^{*}$ & ,000 \\
\hline \multirow[t]{2}{*}{ CTA5 } & Erkek & 83 & 2,6747 & 1,22084 & & \\
\hline & Kadın & 48 & 1,7500 & 91093 & $4,926^{*}$ & ,000 \\
\hline \multirow[t]{2}{*}{ CTA6 } & Erkek & 83 & 2,6627 & 1,23246 & & \\
\hline & Kadın & 48 & 2,1875 & 1,08483 & $2,296^{*}$ & ,000 \\
\hline \multirow[t]{2}{*}{ CTA7 } & Erkek & 83 & 2,5783 & 1,14892 & & \\
\hline & Kadın & 48 & 1,8750 & ,95928 & $3,755^{*}$ & ,000 \\
\hline \multirow[t]{2}{*}{ CTA8 } & Erkek & 83 & 2,5663 & 1,16024 & & \\
\hline & Kadın & 48 & 2,5833 & 1,26883 &,- 078 & ,938 \\
\hline \multirow[t]{2}{*}{ CTA9 } & Erkek & 83 & 2,2410 & 1,01921 & & \\
\hline & Kadın & 48 & 2,7292 & 1,21585 & $-2,346^{*}$ & 021 \\
\hline \multirow[t]{2}{*}{ CTA10 } & Erkek & 83 & 2,5181 & 1,13009 & & \\
\hline & Kadın & 48 & 2,9792 & 1,21146 & $-2,191^{*}$ & , 030 \\
\hline \multirow[t]{2}{*}{ CTA11 } & Erkek & 83 & 2,9036 & 1,13282 & & \\
\hline & Kadın & 48 & 2,8333 & 1,24342 & ,330 & ,742 \\
\hline \multirow[t]{2}{*}{ CTA12 } & Erkek & 83 & 2,6506 & 1,08688 & & \\
\hline & Kadın & 48 & 2,3333 & 93019 & 1,766 & , 080 \\
\hline \multirow[t]{2}{*}{ CTA13 } & Erkek & 83 & 2,8193 & 1,21117 & & \\
\hline & Kadın & 48 & 2,6458 & 1,21146 & 790 & ,431 \\
\hline \multirow[t]{2}{*}{ CTA14 } & Erkek & 83 & 2,6747 & 1,18021 & & \\
\hline & Kadın & 48 & 2,3542 & 1,12021 & 1,526 & ,130 \\
\hline \multirow[t]{2}{*}{ CTA15 } & Erkek & 83 & 2,4337 & 1,12827 & & \\
\hline & Kadın & 48 & 2,7708 & 1,25883 & $-1,579$ & ,117 \\
\hline \multirow[t]{2}{*}{ CTA16 } & Erkek & 83 & 3,3735 & 1,16568 & & \\
\hline & Kadın & 48 & 2,8750 & 1,17826 & $2,349^{*}$ & ,020 \\
\hline \multirow[t]{2}{*}{ CTA17 } & Erkek & 83 & 2,4819 & 1,23329 & & \\
\hline & Kadın & 48 & 1,9375 & ,97645 & $2,786^{*}$ &, 006 \\
\hline \multirow[t]{2}{*}{ CTA18 } & Erkek & 83 & 3,4819 & 1,20326 & & \\
\hline & Kadın & 48 & 3,4583 & 1,30398 & 105 & ,917 \\
\hline
\end{tabular}




\begin{tabular}{lllllll}
\hline CTA19 & Erkek & 83 & 3,2169 & 1,26922 & & \\
& Kadın & 48 & 3,7083 & 1,45804 & $-2,021^{*}$ &, 045 \\
\hline CTA20 & Erkek & 83 & 3,0723 & 1,15593 & & \\
& Kadın & 48 & 3,0000 & 1,32086 &, 327 &, 744 \\
\hline CTA21 & Erkek & 83 & 2,4699 & 1,12983 & & \\
& Kadın & 48 & 2,8125 & 1,24894 & $-1,609$ &, 110 \\
\hline
\end{tabular}

Verilen cevapların puanlaması açısından Tablo 6'daki aralıklar kullanılmıştır. Aralıkların eşit olduğu varsayılmış, aritmetik ortalamalar için puan aralığı 0,80 olarak hesaplanmıştır Cam tavan sendromu alg1 ölçeğindeki sorulara verilen cevapların aritmetik ortalamaların değerlendirme aralığı aşağıdaki tabloda verilmiştir.

Tablo 6. Algısal Ortalamaların Değer Aralıkları

\begin{tabular}{ll}
\hline Aralık & Seçenek \\
\hline $1,00-1,80$ & Hiçbir Zaman Cam Tavan Algısı Yok \\
$1,81-2,60$ & Nadiren Cam Tavan Algısı Var \\
$2,61-3,40$ & Bazen Cam Tavan Algısı Var \\
$3,41-4,20$ & Çoğunlukla Cam Tavan Algısı Var \\
$4,21-5,00$ & Her Zaman Cam Tavan Algısı Var \\
\hline
\end{tabular}

Yukarıdaki tablo göz önüne alınarak, tüm değişkenlerin ortalamaları incelendiğinde, ortalama değeri 3,41'in üzerinde olan sadece üç değişkenin varlığı dikkat çekmektedir. Bu değişkenler, çoğunlukla cam tavan algısına işaret eden, 3. Değişken "Bankacılık sektöründe çalışan kadınlar erkeklere göre, uzun mesailere, şehirlerarası ya da ülkeler arası seyahatlere daha soğuk bakarlar", 18. değişken "Kadın için birinci öncelik çocuğuyla ilgilenmektir" ve 19. değişken "Kadınlar ailede erkeklerden daha fazla sorumluluk üstlenir" değişkenidir. Kadın çalışanların erkek çalışanlara göre, uzun mesaileri, şehirlerarası ya da ülkeler arası seyahatleri istemeyecekleri konusunda kadın çalışanların cam tavan algı seviyeleri oldukça düşük $(M=2,7083)$ olmasına rağmen, erkek çalışanların bu konuda cam tavan algı düzeyinin daha yüksek $(\mathrm{M}=3,5060)$ olduğu görülmektedir. Kadın ve erkek çalışan arasındaki bu farklılığın, istatistiksel açıdan anlamlı olup olmadığına yönelik bağımsız $t$ testi Sig. (2tailed) değeri incelendiğinde, $\mathrm{p}=0,000<0,05$ olduğundan söz konusu farklılığın istatistiksel açıdan anlamlı olduğu gözlenmiştir. Buna göre, 
erkek çalışanların çalışma süresinin uzunluğu ve uzun seyahatlere ilişkin çoğunlukla kadın çalışanların başaramayacağı algısına sahip olduğu söylenebilir. Ayrıca, kadının öncelikli görevinin çocuğu ile ilgilenmek olduğuna ilişkin algı düzeyi erkek çalışanlarda kadın çalışanlara göre daha yüksektir. Ancak, bağımsız t testi sonucuna göre Sig. (2-tailed) değeri 0,917>0,05 olduğundan, kadın ve erkek çalışanların algılarında anlamlı bir farklılık olmadığı söylenebilir. Yani, hem kadın çalışan hem de erkek çalışan kadının öncelikle çocuğuyla ilgilenmesi gerektiği ile ilgili benzer alg1 düzeyine sahiptirler. Aynı şekilde 19. değişken olan "kadınların ailede erkeklerden daha çok sorumluluk üstlenmesi"ne ilişkin alg1 düzeyi kadın çalışanlarda erkek çalışanlara göre daha yüksektir. Bağımsız $t$ testi sonucuna göre Sig. (2-tailed) değeri 0,045<0,05 olduğundan, kadın ve erkek çalışanların algılarında anlamlı bir farklılık olduğu söylenebilir. Yani, kadın çalışan erkek çalışana göre ailede daha fazla sorumluluk almaktadır.

Ayrıca, diğer değişkenler de hem ortalama değerler hem de bağımsız $t$ test sonuçları ile birlikte incelendiğinde, erkek çalışanların kadın çalışanlara yönelik genel olarak anlamlı bir farklılığa $(\mathrm{p}<0,005)$ sahip oldukları ancak, ortalama değerlerin çoğunluğunun 3,41'in altında olması sebebiyle erkek çalışanların kadın çalışanlara yönelik olumsuz algı düzeylerinin çok yüksek olmadığı söylenebilir. Bununla birlikte, kadın çalışanların cam tavan algisının ise oldukça düşük olduğu görülmektedir. Ortalama değeri 3,41'in üzerinde olan üç değişken birlikte ele alınırsa, hem kadın çalışan hem de erkek çalışan kadının önceliğinin çocuğu olduğu konusunda benzer algıya sahiptir. Kadın çalışan erkek çalışana göre ailede daha fazla sorumluluk almaktadır ve bu sayılan iki değişken nedeniyle de erkek çalışanın kadın çalışanın daha fazla mesaiye kalması ya da uzun seyahatlere gitmesi konusunda olumsuz bir tutum sergilediği ve dolayısıyla cam tavan algisı oluşturduğu söylenebilir.

Bununla birlikte, "Cam tavan algısı" genel bir tutum açısından analiz edildiğinde aşağıdaki bulgulara ulaşılmıştır. 
Tablo 7. Genel Cam Tavan Algısı Açısından Bağımsız t-Testi Sonuçları

\begin{tabular}{|c|c|c|c|c|c|c|}
\hline & Cinsiyet & $\mathrm{N}$ & Ortalama & Std. Sapma & $\mathrm{t}$ & $\mathrm{p}$ \\
\hline Genel Cam & Erkek & 83 & 2,7803 & ,56895 & & \\
\hline Tavan Alg1sı & Kadın & 48 & 2,5089 & ,45898 & 2,815 & ,006 \\
\hline
\end{tabular}

Analiz sonuçlarına göre, araştırmaya katılan erkek çalışanların genel olarak cam tavan algısı ortalaması 2,7803 ve kadın çalışanların ortalaması 2,5089'dir. Yani erkek çalışanlar kadın çalışanların kariyerlerine yönelik kadın çalışanlardan daha yüksek düzeyde cam tavan algısına sahip oldukları görülmektedir. Grupların ortalamaları arasında önemli bir fark olduğu gözlenmektedir. Sig. (2-tailed) sonucu da $(\mathrm{p}=0,006)$ grupların ortalamaları arasında önemli bir fark olduğunu göstermektedir. \%95 güven aralığı içinde sig. değeri 0,05 'den küçük çıkmıştır. Dolayısıyla, çalışmanın "1.Ho: Cam tavan algısı, çalışanın cinsiyetine göre farklılık göstermemektedir" hipotezi red edilerek, "1.H1: Cam tavan algısı, çalışanın cinsiyetine göre farklılık göstermektedir" hipotezi kabul edilmiştir. Buna göre, erkek çalışanların kadın çalışanların iş hayatındaki başarısına ve kariyerine yönelik genel olarak daha yüksek düzeyde olumsuz bir tutum içerisinde oldukları yani aslında cam tavan algısına daha çok erkek çalışanların sebep olduğu söylenebilir.

\section{Sonuç, Tartışma ve Öneriler}

Bu araştırma, Adıyaman il ve ilçelerinde faaliyet gösteren bankalarda çalışan kadın ve erkek çalışanların, kadın çalışanların iş yaşamlarında yöneticilik pozisyonlarında görev almalarına ilişkin karşılaştıkları cam tavan algısından kaynaklanan engellerin günümüz şartlarında halen devam edip etmediğinin ve söz konusu cam tavan algısının geçmiş ile karşılaştırılarak bugün itibariyle kadın ve erkek çalışanlar açısından cam tavan alg1 düzeyinin ne durumda olduğunun belirlenmesi amacıyla yapılmıştır.

Çalışmanın analiz kısmında frekans analizi ve güvenilirlik analizi yer verilmiştir. Ayrıca, hipotezlerin testi için bağımsız t-testinden yararlanılmıştır. 21 değişkenden oluşan "Cam Tavan” alg1 ölçeğinin Cronbach's Alpha katsayı değerinin 0,815 olduğu belirlenmiştir. Buna 
göre, kullanılan "Cam Tavan" algı ölçeğinin yüksek derecede güvenilir olduğu ortaya çıkmıştır.

Frekans ve tanımlayıcı analizler kapsamında, tüm değişkenlerin ortalamaları incelendiğinde, ortalama değeri 3,41'in üzerinde (yüksek düzeyde olumsuz cam tavan algısı) olan sadece üç değişkenin varlığı dikkat çekmektedir. Bu değişkenler, yüksek düzeyde cam tavan algısına işaret eden, 3. değişken "Bankacılık sektöründe çalışan kadınlar erkeklere göre, uzun mesailere, şehirlerarası ya da ülkeler arası seyahatlere daha soğuk bakarlar", 18. değişken "Kadın için birinci öncelik çocuğuyla ilgilenmektir" ve 19. değişken "Kadınlar ailede erkeklerden daha fazla sorumluluk üstlenir" değişkenlerdir. Kadın çalışanların erkek çalışanlara göre, uzun mesaileri, şehirlerarası ya da ülkeler arası seyahatleri istemeyecekleri konusunda kadın çalışanların cam tavan algı seviyeleri oldukça düşük ( $M=2,7083)$ olmasına rağmen, erkek çalışanların bu konuda cam tavan algı düzeyinin daha yüksek ( $M=3,5060)$ olduğu görülmektedir. Kadın ve erkek çalışan arasındaki bu farklılığın, istatistiksel açıdan anlamlı olup olmadığına yönelik bağımsız $\mathrm{t}$ testi Sig. (2-tailed) değeri incelendiğinde, $\mathrm{p}=0,000<0,05$ olduğundan söz konusu farklılığın istatistiksel açıdan anlamlı olduğu gözlenmiştir. Buna göre, erkek çalışanların çalışma süresinin uzunluğu ve uzun seyahatlere ilişkin çoğunlukla kadın çalışanların başaramayacağı algısına sahip olduğu söylenebilir. Ayrıca, kadının öncelikli görevinin çocuğu ile ilgilenmek olduğuna ilişkin algı düzeyi erkek çalışanlarda kadın çalışanlara göre daha yüksektir. Ancak, bağımsız t testi sonucuna göre Sig. (2-tailed) değeri 0,917>0,05 olduğundan, kadın ve erkek çalışanların algılarında anlamlı bir farklılık olmadığı söylenebilir. Yani, hem kadın çalışan hem de erkek çalışan kadının öncelikle çocuğuyla ilgilenmesi gerektiği ile ilgili benzer alg1 düzeyine sahiptirler. Aynı şekilde 19. değişken olan "kadınların ailede erkeklerden daha çok sorumluluk üstlenmesi"ne ilişkin algı düzeyi, kadın çalışanlarda erkek çalışanlara göre daha yüksektir. Bağımsız t testi sonucuna göre Sig. (2tailed) değeri $0,045<0,05$ olduğundan, kadın ve erkek çalışanların algılarında anlamlı bir farklılık olduğu söylenebilir. Yani, kadın çalışan erkek çalışana göre ailede daha fazla sorumluluk almaktadır.

Ayrıca, diğer değişkenler de hem ortalama değerler hem de bağımsız $t$ test sonuçları ile birlikte incelendiğinde, erkek çalışanların kadın çalışanlara yönelik genel olarak anlamlı bir farklılığa $(\mathrm{p}<0,005)$ sahip oldukları 
ancak, ortalama değerlerin çoğunluğunun 3,41'in altında olması sebebiyle erkek çalışanların kadın çalışanlara yönelik olumsuz algı düzeylerinin çok yüksek olmadığı söylenebilir. Bununla birlikte, kadın çalışanların cam tavan algisının ise oldukça düşük olduğu görülmektedir. Ortalama değeri 3,41'in üzerinde olan üç değişken birlikte ele alınırsa, hem kadın çalışan hem de erkek çalışan kadının önceliğinin çocuğu olduğu konusunda benzer algıya sahiptir. Kadın çalışan erkek çalışana göre ailede daha fazla sorumluluk almaktadır ve bu sayılan iki değişken nedeniyle de erkek çalışanın kadın çalışanın daha fazla mesaiye kalması ya da uzun seyahatlere gitmesi konusunda olumsuz bir tutum sergilediği ve dolayısıyla cam tavan algısı oluşturduğu söylenebilir.

Analiz sonuçlarına göre, araştırmaya katılan erkek çalışanların genel olarak cam tavan algısı ortalaması 2,7803 ve kadın çalışanların ortalaması 2,5089'dir. Yani erkek çalışanlar kadın çalışanların kariyerlerine yönelik kadın çalışanlardan çok daha yüksek düzeyde cam tavan algısına sahip oldukları görülmektedir. Bağımsız t-testi Sig. (2-tailed) sonucu da $(\mathrm{p}=0,006)$ grupların ortalamaları arasındaki bu farklılığın anlamlı olduğunu göstermektedir. \%95 güven aralığ içinde sig. değeri 0,05 'den küçük çıkmıştır. Dolayısıyla, çalışmanın sıfır hipotezi $\left(\mathrm{H}_{0}\right)$ reddedilerek, alternatif hipotez $\left(\mathrm{H}_{1}\right)$ hipotez kabul edilmiştir. Buna göre, erkek çalışanların kadın çalışanların iş hayatındaki başarısına ve kariyerine yönelik genel olarak daha yüksek düzeyde olumsuz bir tutum içerisinde oldukları yani aslında cam tavan algısına daha çok erkek çalışanların sebep olduğu söylenebilir.

Bu çalışma sonuçları ile Üçyıldız (2017) tarafından çalışma sonuçları birlikte değerlendirildiğinde, kadın çalışanların cam tavan algısının yok denecek kadar az olduğu görülmektedir. Çünkü, Üçyıldız (2017) tarafından da belirtildiği gibi, günümüz iş dünyasında yer alan kadın çalışanlar, erkekler kadar yöneticilik özelliklerine sahip olduklarına, iş dünyasının güçlüklerine karşı erkekler kadar direnç gösterebileceklerine, hızlı ve mantıksal kararlar alabileceklerine, üst düzey yöneticilikte başarılı olacaklarına inanmaktadırlar. Buna göre, kadın çalışanlar açısından "cam tavan kırılmıştır" denilebilir. Ancak, bu sonuç, Gül ve Oktay (2009) tarafından yapılan çalışma ile örtüşmemektedir. Gül ve Oktay (2009), kadınların cam tavan sendromuna karşı çıkmak yerine kabullendiklerini tespit etmiştir. 
Ayrıca bu çalışmada ortaya çıkan "Bankacılık sektöründeki kadın çalışanlardaki cam tavan algısının yok denecek kadar az olması" bulgusu, Eroğlu ve İrdem (2016) tarafından yapılan çalışmada belirtildiği üzere, "kadınların bankacılık mesleğine uygun olarak algılanmalarını öngören toplumsal cinsiyet farklılıklarından kaynaklandığı" görüşünü destekler niteliktedir.

Diğer taraftan, bu çalışma ile, erkek çalışanların toplumsal cinsiyete dayalı ayrımcılık sebebiyle halen kadın çalışanlara yönelik basmakalıp yargılara sahip oldukları, ancak sözkonusu cinsiyet ayrımı algısının eskiye nazaran düşme eğiliminde olduğu sonucuna ulaşılmıştır.

Çalışmada elde edilen erkek çalışanların kadınların yönetici olmalarına yönelik "basmakalıp yargılara" sahip oldukları yönündeki bu sonuç, Ergeneli ve Akçamete (2004) tarafından yapılan çalışmanın sonuçları ile çelişmektedir. Ancak, Ergeneli ve Akçamete (2004) tarafından yapılan çalışma sonucuna göre; "bankacılık sektöründe çalışan erkeklerin, kadınlara göre kadınların üst düzey yönetici olmalarına daha olumlu yaklaştığı" nın ortaya konulmuş olması ile 2018 yılında yapılan bu araştırma sonucunda ortaya çıkan cam tavan sendromu algısında ortaya çıan olumlu yöndeki gelişme birbirini destekler niteliktedir.

Çalışma sonuçları genel olarak değerlendirildiğinde cam tavan sendromunun ülkemizde halen devam ettiği, ancak sendromun geçmişteki gibi kadınların kendilerine yönelik olumsuz düşüncelerden (yetersizlik, eğitimsizlik vb) ziyade erkeklerin konuya ilişkin önyargılı bakış açısından kaynaklandığı, ancak bu önyargılı bakış düzeyinin de azalmakta olduğu görülmektedir.

Araştırmada elde edilen bulgular ışığında, insan kaynakları yöneticilerinin örgütlere işe alım süreçlerinde başvuruları tarafsız olarak değerlendirmeleri, kadın ve erkek çalışanlara eşit muamelenin yapılması ve en önemlisi kadın çalışanlara yasal haklarının verilmesi önerilebilir. Bununla beraber, kadın çalışana yönelik mentörlük desteğinin verilmesi, devlet tarafından kadın girişimciliğinin daha fazla oranda desteklenmesi ve özellikle erkek çalışana yönelik, toplumsal cinsiyet eşitsizliği ve dolayısıyla cam tavan algisına sebebiyet veren basmakalıp yargıların azaltılması ve hatta tamamen söz konusu yargıların ortadan kaldırılması için insan hakları, çalışma hakları, toplumsal cinsiyet eşitliği ve demokrasi ve benzeri 
konularda eğitimler sürekli olarak verilmelidir. Korkmaz (2016) tarafından belirtildiği gibi, cam tavanı kırmanın her ne kadar toplumsal ve örgütsel bir çaba gerektirse de, kadının bu sorunla baş edebilmesi için öncelikle özgüveninin geliştirilmesi gerekmektedir. Bu bağlamda kadın çal1şanlara özgüven geliştirici eğitimlerin ve mentörlük desteklerinin verilmesi insan kaynakları yöneticilerinin de plan ve programları içerisinde yer almalıdır.

Ayrıca, Yavuz ve Uzun (2019) tarafından yapılan çalışmada, cam tavanı aşmaya yönelik öneriler olarak bireysel ve kurumsal stratejilerden bahsedilmiştir. Bireysel stratejilerin; yükseköğretim ve mesleki eğitim programlarına katılım, danışmanlık alma (mentor yardımı), kadınlardan beklenenin üzerinde performans sergileme, çoklu rollerinden bazı durumlarda feragat etme, kariyer ve sosyal ilişkilerini geliştirmeye yönelik programlardan yararlanma şeklinde olduğu belirtilmiştir. Ayrıca, kurumsal stratejilerin ise; örgütlerdeki erkek egemenliğini azaltmaya yönelik politikalar, aile dostu örgütler oluşturma ve pozitif ayrımcllık ilkeleri doğrultusunda politikalar oluşturma şeklinde olabileceğinden söz edilmiştir. Bu bağlamda, özellikle erkek çalışanlarda mevcut olan ve cinsiyete dayalı ayrımcllığa yol açan önyargıların aşılarak cam tavanın kırılmasına yönelik erkek çalışanlara kurumsal stratejilerin uygulanması faydalı olacaktır. Sadece kurumlar değil, aynı zaman da pozitif ayrımcılığın toplum ve devlet tarafından da uygulanarak zamanla içselleştirilen bir eşitlik algısının oluşturulması, cam tavan algısının aşılması sürecini hızlandıracaktır. Kadınların iş hayatlarındaki cam tavan algısının aşılması ya da kırılması sadece kadınların kazanımlarını değil özellikle toplumun ve ülkenin de uzun vadeli kazanımlarını sağlayacaktir.

$\mathrm{Bu}$ çalışma ile elde edilen bulgular sadece Bankacılık sektöründeki çalışanlar ve Adıyaman ili ile sınırlıdır. Sonuçların ülke genelindeki diğer bankalarda çalışan kadınlar için de geçerli olup olmayacağı başka çalışmalar ile araştırılabilir. 


\title{
EXTENDED ABSTRACT
}

\section{Was The Glass Ceiling Perception of The Female Employees Broken up? Are The Male Employees Still Discriminating Gender?: The Exampe of Adiyaman Banking Sector}

\author{
Gülşen Kırpık \\ Adryaman university
}

Glass ceiling syndrome, which first appeared in the 1970s and was used to describe invisible obstacles that women face in their working lives, actually speaks of abstract barriers. Glass ceiling syndrome was first defined as invisible, artificial obstacles that prevented women from moving to upper levels in the US. Numerous studies on glass ceiling syndrome have been found in both national and foreign literature. However, in the last 10 years there has not been any study including a qualitative and quantitative study on whether there is a positive or negative change in the perception of glass ceiling in the male or female employee. In this context, in this study, it has been investigated to what extent glass ceiling syndrome is perceived in terms of male and female employees in banks operating in Adiyaman provinces and districts. In addition, it was aimed to investigate whether the discrimination of male employees against the female employee is still continuing. However, if discrimination continues, it is aimed to investigate whether there is a decrease in the level of negative perception compared to the past. It is believed that this gap in the literature about the study will be filled.

For the purpose of determining the positive or negative differences in the glass ceiling perception from the point of view of female and male employees, the data were obtained from the primary source with the faceto-face survey method. The questionnaire used in the study consists of 27 questions, 6 of which are related to the demographic characteristics of the employee, and 21 of which are from the statement of glass ceiling perception. For the scale of Glass Ceiling Syndrome used, the studies conducted by Ertaş, Çiftçi Kıraç and Kıraç (2018), Girginer and Ertuğ (2017), Bingöl, 
Aydoğan, Şenel and Erden (2011) and Karaca (2007) were used. The SPSS 16.0 statistical program was used to analyze the data set. The results obtained by the independent $t$-test were compared in terms of differences and similarities with other similar study results conducted in our country between 2004-2019. In this way, the aim of the study has been reached.

When the statistical results of descriptive variables are evaluated; it was observed that the majority of the employees who participated in this study consisted of male, young and customer representative employees, the majority of which had undergraduate and higher education level and the majority of seniority level was 5 years and below. According to the results of the study, the average glass ceiling perception of male employees participating in the study is 2,7803 and the average of female employees is 2,5089 . In other words, it is seen that male employees have a higher level of glass ceiling perception than female employees. There is a significant difference between the averages of the groups. The significance (2tailed) result $(\mathrm{p}=0.006)$ indicates a significant difference between the averages of the groups. The $p$ value was smaller than 0.05 in the $95 \%$ confidence interval. Therefore, the null hypothesis of the study was rejected and the alternative hypothesis was accepted. Accordingly, it can be said that the male employees have a higher level of negative attitude towards the success of their female employees and their career, in other words, the fact that the glass ceiling perception is mostly caused by male employees.

When the results of the study are evaluated generally, it can be said that glass ceiling syndrome is still continuing in our country. However, it is seen that the syndrome is caused by the prejudiced point of view of male employees rather than negative thoughts (inadequacy, lack of education etc.) of women as in the past. Nevertheless, when compared to the past, it was observed that the level of prejudices in male employees is also decreasing.

When the results of this study are evaluated together with the results of the study conducted by Üçyıldız (2017), it is seen that the glass ceiling perception of the female employees is negligible. Because, as stated by Üçyıldiz (2017), women workers in today's business world believe that they have managerial characteristics as much as men, they can resist as much as men against the difficulties of business world, they can make fast and 
logical decisions, and they will be successful in senior management. Accordingly, it can be said that the glass ceiling in terms of female employees is broken.

However, this result does not coincide with the study conducted by Gül and Oktay (2009). Gül and Oktay (2009) found that women accepted as opposed to rejecting glass ceiling syndrome. In addition, the finding that the glass ceiling perception of the female employees in the banking sector is almost negligible, supports the view that women are perceived as appropriate to the banking profession and that they arise from gender differences as stated in the study by Eroğlu and Irdem (2016).

The results of this study, in which the male employees obtained in the study have stereotypes for women to be managers, contradict the results of the study by Ergeneli and Akçamete (2004).However, according to the results of the study conducted by Ergeneli and Akçamete (2004); As the results of this study conducted in 2018, the positive development in the perception of glass ceiling syndrome has been supported by the fact that the men working in the banking sector have more positive approach towards women than women.

In the light of the findings obtained from the research, it can be suggested that human resources managers evaluate the applications impartially in recruitment processes, equal treatment of female and male employees and most importantly give legal rights to female employees. As stated by Korkmaz (2016), although it is a social and organizational effort to break the glass ceiling, it is necessary to develop the self-confidence of the woman in order to cope with this problem. In this context, giving selfconfidence training and mentoring support to female employees should be included in the plans and programs of human resources managers.

On the other hand, the findings obtained from this study are limited only to the employees in the banking sector and to the province of Adiyaman. It can also be investigated by other studies whether the results will be valid for women working in other banks throughout the country.

\section{Kaynakça / References}

Akdemir, B. ve Çalış-Duman, M. (2017). Kadın çalışanların performansinda cam tavan sendromu engeli. International Journal of Academic Value Studies, 3(15), 517-526. 
Aksu, A., Çek, F. ve Şenol, B. (2013). Kadınların müdür olmalarının önündeki cam tavan ve cam tavanı aşma stratejileri'ne ilişkin ilköğretim okulu müdürlerinin görüşleri, Kocaeli Üniversitesi Sosyal Bilimler Dergisi, 25, 133-160.

Battal, F., Akgül, S., Şengün, H. ve Kılıçaslan, Ş. (2017). Çelişik duygulu cinsiyetçilik ve cam tavan sendromu ilişkisi. Sosyal Bilimler Ensitüsü Dergisi, 34, 1-26.

Bilkay, T. A. (2017). Çalışan kadınların kariyer engelleri ve cam tavan sendromu algilamalarının iş motivasyonlarına etkilerini belirlemeye yönelik bir araştırma: Sağılk Bakanlığı Merkez Teşkilatı örneği. Yüksek Lisans Tezi, İşletme Anabilim Dalı Hastane İşletmeciliği Bilim Dalı, 08.05.2019 tarihinde, file:///C:/Users/acer/Downloads/dosya_15ff8274b518e80958d44619cbb6d152\%20(1).pdf adresinden erişilmiştir.

Bingöl, D., Aydoğan, E., Şenel, G. ve Erden, P. (2011). Cam tavan sendromu ve kadınların hiyerarşik yükselmelerindeki engeller: TC. Enerji ve Tabii Kaynaklar Bakanlığı ankara merkez teşkilatı örneği. İşletme Fakültesi Dergisi, 12(1), 115-132.

Cotter, D. A. vd. (2001). The glass ceiling effects. Social Forces, 80(2), 655681.

Çarıkçı, İ., Çiftçi, M. ve Derya, S. (2010). İş-aile yaşam çatışması: Türkiye'deki kadın yöneticiler üzerinde bir uygulama. Süleyman Demirel Üniversitesi Vizyoner Dergisi, 2(2), 53-65.

Çizel, R. B., Çizel, B. (2014). Kadın öğretmenlerin cam tavan sendromu algisın etkileyen faktörler. Mediterranean Journal of Humanities, 4(1), 63-69.

Demir, H. ve Kartal, N. (2018). Sağlık çalışanlarının cam tavan algısı. Genel Tip Dergisi, 28(2), 48-56.

Dzuayatin, S. R. ve Edwards, J. (2010). Itting our heads on te glass ceiling: Women and leadership in education in Indonesia. Studia Islamika, $17,200-232$.

Erçen, A. E. Y. (2008). Kadınların cam tavanı aşma stratejileri: Büyük ölçekli türk işletmelerinde bir inceleme. Yayınlanmamış Doktora Tezi, Çukurova Üniversitesi Sosyal Bilimler Enstitüsü İşletme Anabilim Dalı, Adana 
Ergeneli, A. ve Akçamete, C. (2004). Bankacılıkta cam tavan: Kadın ve erkeklerin kadın çalışanlar ve üst yönetime yükselmelerine yönelik tutumları. Hacettepe Üniversitesi İktisadi ve İdari Bilimler Dergisi, 22 (2), 85-109.

Eroğlu, F. ve İrdem, Ş. (2016). Toplumsal cinsiyet ayrımcılığ1 ve yönetim kademelerindeki yansımaları, Pamukkale İşletme ve Bilişim Yönetimi Dergisi, 3(2), 11- 13.

Ertaş, H., Çiftçi Kıraç, F. ve Kıraç, R. (2018). Cam tavan sendromu:Özel hastane uygulaması. Akademik Sosyal Araştırmalar Dergisi, 6(85), 446-455.

Fındık, E. (2016). İş-aile çatışmasının cam tavan sendromu üzerindeki ekisi: Otel İşletmelerinde bir araştırma. Yayınlanmamış Yüksek Lisans Tezi, Nevşehir Hacı Bektaş Veli Üniversitesi Sosyal Bilimler Enstitüsü Turizm İşletmeciliği Anabilim Dalı, Nevşehir.

Gül, H., Oktay, E. (2009). Türkiye ve dünyada kadınların çalışma hayatında yaşadıkları cam tavan algıları üzerine kavramsal bir çalışma. SÜ İ̈BF Sosyal ve Ekonomik Araştırmalar Dergisi, 9(18), 421436.

Güner, E. S. (2018). Kadın çalı̧̧anlarda cam tavan sendromu ve kariyer planlaması: İstanbul İli üzerine bir araştırma. Yayınlanmamış Yüksek Lisans Tezi, İstanbul Gelişim Üniversitesi Sosyal Bilimler Enstitüsü İşletme Anabilim Dalı, İstanbul.

Kalaycı, Ş. (2016). SPSS uygulamalı çok değiş̧kenli istatistik teknikleri. (7.bsm), Ankara:Asil Yayın Dağıtım Ltd. Şti.

Kara, E. (2019). The effect of gender in the relationship of career development and job satisfaction for female employees. Uluslararası İktisadi ve İdari Incelemeler Dergisi, 24, 59-72.

Karabıyık, İ. (2012). Türkiye'de çalışma hayatında kadın istihdamı. Marmara Üniversitesi İiBF Dergisi, 32(1), 231-260.

Karaca, A. (2007). Kadın yöneticilerde kariyer engelleri: Cam tavan sendromu üzerine uygulamalı bir araştırma. Yayınlanmamış Yüksek Lisans Tezi. Selçuk Üniversitesi Sosyal Bilimler Enstitüsü İşletme Anabilim Dalı, Konya.

Karcıoğlu, F. ve Leblebici, Y. (2014). Kadın yöneticilerde kariyer engelleri: Cam tavan sendromu üzerine bir uygulama. Atatürk Üniversitesi İktisadi ve İdari Bilimler Dergisi, 28(4), 1-21. 
Korkmaz, H. (2014). Yönetim kademelerinde kadına yönelik cinsiyet ayrımcllığı ve cam tavan sendromu, Asos Journal Akademik ve Sosyal Araştırmalar Dergisi, 2(5), 1-14.

Korkmaz, H. (2016). Yönetimde Kadın ve Cam Tavan Sendromu, Alternatif Politika Toplumsal Cinsiyet Özel Sayısl, 08.05.2019 tarihinde https://www.academia.edu/29598893/Hatun_KORKMAZ__Y\%C3\%96NET\%C4\%B0MDE_KADIN_VE_CAM_TAVAN_SENDROMU adresinden erişilmiştir.

Kulualp, G. (2015). Stratejik insan kaynakları yönetiminde cam tavan sendromu engellerini aşmak. Kamu-İş Dergisi, 14(1), 99-123.

Lathabhavan, R. ve Balasubramanian, S. A. (2017). Glass ceiling and women employees in asian organizations: A tri-decadal review. Asia Pacific Journal Of Business Administration, 9(3), 232-246.

Lockwood, N. (2004). The glass ceiling: Domestic and international perspectives. researc quarterly. Society For Human Resources Management, 1-10.

Love, J.F. (2017). Investigatin the glass ceiling: Ow women in top media management sattered te glass ceiling. Master Thesis, The University of Mississippi Department of Journalism. Mississsippi.

Menteş, S. A., (2018). Türk bankacılık sektöründe cam tavan sorunu. Social Sciences Research Journal, 5, 4-1.

Mizrahı, R. ve Aracı, H. (2010). Kadın yöneticiler ve cam tavan sendromu üzerine bir araştırma, Organizasyon ve Yönetim Bilimleri Dergisi, 2(1), 216-223.

Öğüt, A. (2006). Türkiye'de kadın girişimciliğinin ve yöneticiliğin önündeki güçlükler: Cam tavan sendromu. Yayınlanmamış Yüksek Lisans Tezi, Selçuk Üniversitesi Sosyal Bilimler Enstitüsü İşletme Anabilim Dal, Konya.

Örücü, E., Kılıç, R. ve Kılıç, T. (2007). Cam tavan sendromu ve kadınların üst düzey yönetici pozisyonuna yükselmelerindeki engeller: Balıkesir ili örneği. Yönetim ve Ekonomi Dergisi, 14(2), 117-135.

Özyer, K. ve Azizoğlu, Ö. (2014). İş hayatında kadınların önündeki cam tavan engelleri ile algılanan örgütsel adalet arasındaki ilişkisi. Ekonomik ve Sosyal Araştırmalar Dergisi, 10(1), 95-106. 
Sarığlu, Z. B. (2018). Cam tavan sendromu: Ölçek uyarlama çalışması ve demografik değişkenler açısından bir analiz. Yayınlanmamış Yüksek Lisans Tezi, Bahçeşehir Üniversitesi Sosyal Bilimler Enstitüsü İşletme Anabilim Dalı, İstanbul.

Soysal, A. ve Baynal, T. (2016). Sağlık kurumlarında cam tavan sendromu: Kayseri özel sağlık kurumlarında bir araştırma. KSÜ Sosyal Bilimler Dergisi, 13(2), 225- 264.

Sönmez, P. S. ve Bayraktar, O. (2017). Cam tavan sendromunun tükenmişlik ile olan ilişkisinin örgütsel bağlllığa olan etkisinin sonuçları. İstanbul Ticaret Üniversitesi Dış Ticaret Enstitüsü Working Paper Serious, 01/Wps No: 73.

Taşkın, E. (2012). Kadın yöneticilerin cam tavan algısının cam tavanı aşma stratejilerine etkisi: Bursa örneği. Dumlupınar Üniversitesi Sosyal Bilimler Dergisi, 33, 19-34.

Uzun, G. (2005). Kadın ve erkek yöneticilerin liderlik davranışları arasındaki farklılıklar ve ankacılık sektöründe uygulama. Yayınlanmamış Yüksek Lisans Tezi, Çukurova Üniversitesi Sosyal Bilimler Enstitüsü İşletme Anabilim Dalı, Adana.

Üçyıldız, U. H. (2017). Kadın çalışanların cam tavan sendromu algılamaları: Ege bölgesinde faaliyet gösteren seyahat acentalarinda bir araştırma, Yayınlanmamış Yüksek Lisans Tezi, Mersin Üniversitesi Sosyal Bilimler Enstitüsü İşletme Anabilim Dalı, Mersin.

Wirth, L., (2001). Breaking through the glass ceiling women in management. Geneva: International Labour Office.

Yavuz, E. ve Uzun, A. 2019. Türkiye'de 2000-2018 yılları arasında cam tavan kavramı ile ilgili çalışmaların incelenmesi ve yorumlanması. AVRASYA Uluslararası Araştırmalar Dergisi, 7(16), 697 - 718.

Yazıcıoğlu, Y. ve Erdoğan, S. (2004). Spss uygulamalı bilimsel araştırma yöntemleri. Ankara:Detay Yayıncilık,

Yegengil, E. (2018). Kadının Kariyer yaşamında karşılaş̧ı̆̆ı engeller ve cam tavan. Yayınlanmamış Yüksek Lisans Tezi, Ufuk Üniversitesi Sosyal Bilimler Enstitüsü İşletme Anabilim Dalı, Ankara.

Yıldız, S., Alhas, F., Sakal, Ö. ve Yıldız, H. (2016). Cam uçurum: Kadın yöneticiler cam tavanı ne zaman aşar?. Ankara Üniversitesi SBF Dergisi, 71(4), 1119-1146. 
Yılmaz, B. ve Okutan, E., (2017). Cam tavan sendromu ve kadınların kariyer engelleri: Mersin Büyükşehir Belediyesi örneği, 2. Uluslararası Politik, Ekonomik ve Sosyal Araştırmalar Kongresi, 99-101.

https://www.tbb.org.tr/tr/bankacilik/banka-ve-sektor-bilgileri/veri-sorgulama-sistemi/illere-ve-bolgelere-gore-bilgiler/73 E. Tarihi: 19.02.2019

\section{Kaynakça Bilgisi / Citation Information}

Kırpık, G. (2019). Kadın çalışanlarda cam tavan algısı kırıldı mı? erkek çalışanlar halen cinsiyet ayrımcılığı yapıyorlar mı?: Adıyaman bankacılık sektörü örneği. OPUS-Uluslararası Toplum Araştırmaları Dergisi, 12(18. UIK Özel Say1s1), 341-372. DOI: 10.26466/opus.583816. 